\title{
Who lived on the Swiss Plateau around 3300 BCE? Analyses of commingled human skeletal remains from the dolmen of Oberbipp
}

\author{
Inga Siebke ${ }^{1}$, Noah Steuri ${ }^{2}$, Anja Furtwängler ${ }^{3}$, Marianne Ramstein ${ }^{4}$, Gabriele Arenz ${ }^{1}$, \\ Albert Hafner ${ }^{2,5}$, Johannes Krause ${ }^{3,6,7}$, Sandra Lösch ${ }^{1}$
}

\begin{abstract}
${ }^{1}$ Department of Physical Anthropology, Institute of Forensic Medicine, University of Bern, Bern, Switzerland

${ }^{2}$ Institute of Archaeological Sciences, Prehistoric Archaeology, University of Bern, Bern, Switzerland

${ }^{3}$ Institute for Archaeological Sciences, Archaeo- and Palaeogenetics, University of Tübingen, Tübingen, Germany

${ }^{4}$ Archaeological Service of the Canton of Bern, Bern, Switzerland

${ }^{5}$ Oeschger Center for Climate Change Research, University of Bern, Bern, Switzerland

${ }^{6}$ Max Planck Institute for the Science of Human History, Jena, Germany

${ }^{7}$ Senckenberg Centre for Human Evolution and Palaeoenvironment, University of Tübingen, Tübingen, Germany
\end{abstract}

\section{Correspondence:}

Sandra Lösch, Department of Physical Anthropology, Institute of Forensic Medicine, University of Bern, Sulgenauweg 40, 3007 Bern, Switzerland.

Email: sandra.loesch@irm.unibe.ch

\section{Funding information:}

Multidisciplinary research approach to the Swiss Oberbipp dolmen in the context of the Neolithic revolution in Central Europe, Grant/ Award Number: CR31I3L_157024; Multidisziplinäre Untersuchung des Schweizer Dolmen Grabes von Oberbipp im Kontext der Neolithisierung Europas, Grant/Award Num- ber: KR4015/4-1

Keywords: aDNA, anthropology, commingled remains, dolmen, Late Neolithic, MNI, Switzerland

\begin{abstract}
Nowadays, the discovery and excavation of an almost intact Late Neolithic dolmen is rare, as those monuments were often visible in the landscape and have been investigated or destroyed in earlier times; therefore, information about the buried individuals has often been lost. The excavation of the dolmen, a stone grave chamber, from Oberbipp, Switzerland, in 2012 provided a unique opportunity to study human skeletal remains from a Late Neolithic collective burial (3350-2650 BCE). Over 2,000 fragmented and commingled skeletal elements were recovered and form the basis of this morphological study. Established morphological methods were employed to evaluate the minimum number of individuals, age at death, sex, stature, and the presence of pathological alterations and trauma. Sex was determined additionally by aDNA analysis. Elements of the entire human skeleton were recovered indicating a primary burial site. At least 42 individuals (femora) from all age classes (57\%:43\% adults to subadults) were buried in the dolmen. Based on aDNA analysis $(n=23$, partes petrosae) slightly more males than females (44\%:35\% males to females, $22 \%$ indeterminate) were recovered. Stature was estimated from complete femora $(\mathrm{n}=3)$ indicating an average body height between 154-157 cm. Pathological alterations and trauma could be observed on several bones, however, without indications for major interpersonal violence. The caries intensity of Swiss samples seems to be higher compared with other Neolithic European sites. A possible separation of burial areas for males and females based on the recovery of skeletal elements within the dolmen along with aDNA results is postulated. In addition, this article contributes to a better understanding of Late Neolithic populations in Central Europe.
\end{abstract}




\section{Introduction}

For centuries, people have been fascinated by prehistoric megalithic structures, which are often well visible in the landscape. The discovery of a well preserved dolmen still containing human remains is extremely rare nowadays. However, in 2012, such a dolmen was excavated in the village of Oberbipp, situated on the southern slopes of the Jurassic mountains in the Canton of Bern, Switzerland (Figure 1, No. 42; Figure 2a). It is one of the few megalithic collective burial sites with in situ human remains in Switzerland (Ramstein, Schimmelpfennig, \& Lösch, 2014; Siebke et al., 2018). Although the Neolithic period of Switzerland is marked by settlement sites of the pile dwelling type on lakeshores (Palafittes, 2015), it is less well known for burial sites other than the eponymous site of Sion Petit-Chasseur (Figure 1, Nos. 35-39). This renders the find of the dolmen at Oberbipp particularly significant for the interpretation of Late Neolithic population demographics.

In an area of approximately $200 \mathrm{~km}$ around the dolmen of Oberbipp, at least 41 sites of megalithic collective burials are currently known, whereas skeletal remains were documented for only 18 sites (Steuri, 2017).

In some cases, an anthropological evaluation has been carried out. However, the excavations took place mainly in the late 19th and early 20th centuries, and often information about the skeletal remains have been lost. For the remaining 23 megalithic collective burials, the presence of skeletal remains at the time of the excavation is unknown. In addition, radiocarbon data are only available for seven of the excavated dolmen (Steuri, 2017). Until now, Oberbipp represents one of only few almost intact dolmen in Switzerland (Figure $2 \mathrm{a}$ ), which has been documented entirely and by state-of-the-art methods, such as 3D documentation (Ramstein et al., 2014; Siebke et al., 2018).

\subsection{The archaeological context of the inhumations at Oberbipp}

The individuals were buried in extended supine position (Figure $2 \mathrm{~b}$ ) in an approximately $2 \mathrm{~m}^{2}$ chamber. They were placed in the dolmen with the skulls mostly towards the entrance in the south-east (Ramstein et al., 2014). The inhumations were found highly disturbed with two large disturbances-one at the back (north-west) and one at the centre of the dolmen. Skeletal elements still in anatomical association were mainly documented in the area of the lower limbs, and the upper body at the south-west wall. It was not possible to determine different occupation periods based on the stratigraphy of the inhumations. Because dolmen graves were often (re-)used over long periods, this question was addressed with systematic radiocarbon dating (Steuri et al., submitted). In addition, it could be documented that the whole dolmen was affected by at least two flooding events and possible animal and human activity in the inside.

Only a few artefacts were found inside the grave chamber, namely five flint arrowheads, four animal tooth amulets, and two probably marine mollusca (Ramstein et al., 2014). Based on the radiocarbon data, the dolmen of Oberbipp is contemporaneous with lake shore settlements of the Horgen phase (Hafner \& Suter, 2003) within the Late Neolithic of Switzerland (3400-2800 BCE).

\subsection{Anthropological importance of Oberbipp}

In general, the Neolithic period in its entirety has often been subject to anthropological, archaeological, and paleogenetic studies (e.g., Bickle \& Whittle, 2013; Haak et al., 2010). Around 2800 BCE, the genetic and archaeologic records postulate a second migration wave into Central Europe (e.g., Allentoft et al., 2015; Haak et al., 2015).

The structures and material cultures of pile dwelling sites of the Swiss Neolithic are well investigated, while less attention has been paid to the inhabitants of these settlements - their population structures, lifestyle, and dietary habits. The main reason might be that there are no burials directly related to pile dwellings and only a few burial sites are preserved in the archaeological record (Doppler, 2012; Hafner \& Suter, 2003). Moreover, although the interpretation of stone cists (western and central Switzerland) with initially single burials ( 5000 BCE) and later multiple burials (4300-3200 BCE) seems to be straight forward regarding burial practices and demographic structures, it becomes more complex with the change to collective burials in dolmen (3300-2200 BCE). Based on the different burial practices 
observable in western, central, and eastern Switzerland during the Neolithic (Hafner \& Suter, 2003; Stöckli, Niffeler, \& Gross-Klee, 1995), differences of these populations have to be assumed as well. There is no information about skeletal assemblages and burial practices for dolmen in the wider geographic area. Therefore, the dolmen of Oberbipp might not only provide demographic information but may also provide insights into the burial practices of these Neolithic farmers.

The aim of this anthropological study therefore is to present the minimum number of individuals (MNI), age at death, sex, and stature distribution as well as pathological and traumatic alterations and to discuss it in the context of other Neolithic sites.

\section{Materials and Methods}

Bones were recorded at excavation as either single, clearly distinguish- able bones with no association to other fragments, several bones that were in anatomical association, or bone complexes without clear con- text. They were morphologically analyzed in detail in the laboratory and classified with regard to their anatomical features and position similar to Mack, Waterman, Racila, Artz, and Lillios (2016) and Osterholtz, Baustian, Martin, and Potts (2014). The preservation and representation of the skeletal remains were not further evaluated due to overall fragmentation and taphonomic alterations. For further biochemical analyses, the right partes petrosae $(\mathrm{n}=23)$ were sampled for aDNA (Furtwängler et al., 2018, in preparation), stable isotope analyses, and radiocarbon dating (Siebke et al., in preparation) to ensure a congruent dataset and to overcome the limitations of commingled remains.

\subsection{Biological profile}

The MNI was established using the most often occurring and identifiable bones, which could be assigned to a side of the body and an age category (Mack et al., 2016; Osterholtz et al., 2014). To ensure that for the MNI calculation each individual was only included once, an overlap of features had to be present of the fragmented remains.

The bones were assigned an age-at-death class following the development stages of bone growth defined by Scheuer and Black (2004). The following age classes were defined: neonate (skeletal maturation around birth), Infans I (skeletal maturation between 0-6 years of age), Infans II (skeletal maturation between 7-13 years of age), juvenile (skeletal maturation between 14-20 years of age), and adult (complete skeletal maturation; over 20 years of age). The age- at-death distribution of the individuals was established based on the most often occurring bone element that could be sided and aged.

The sex was evaluated for adults based on morphological features as described by Sjøvold (1988) and on femoral measurements F6, F8, and F18 based on Martin (1914). Furthermore, the sex distribution was established based on aDNA analysis of 23 right partes petrosae. For the genetic sex determination, 30-100 mg of bone powder was sampled from the right petrous bone. DNA was extracted according to Dabney et al. (2013). Sequencing libraries were prepared after Meyer and Kircher (2010). To allow multiplex sequencing, the libraries were double indexed (Kircher, Sawyer, \& Meyer, 2012) and pooled equimolarly for single-end sequencing on a HiSeq4000 for 75 cycles. The raw data were processed with the EAGER pipeline (Peltzer et al., 2016) with a mismatch parameter (-n) of 0.01 and the seeding disabled (-l) 1,000. After a quality filter of the mapped reads of 30, sex determination was performed after Mittnik, Wang, Svoboda, and Krause (2016) on all mapped reads and after filtering for reads with aDNA characteristic damage (Skoglund et al., 2014).

The maximum living stature was estimated from complete femora only. Measurement F1 (maximum length) after Martin (1914) was taken, and the stature was calculated following Pearson (1899). In cases of uncertainty of the sex, the average of both sexes was taken.

\subsection{Anatomical variations, pathological and traumatic alterations}

Anatomical variations described in White et al. (2012; metopic sutures, sutural bones [incl. Inca bones], sternal foramen, costoclavicular sulcus, septal aperture, number of sacral vertebrae, spina bifida, expanded sacral hiatus, third trochanter, vastus notch, patellar spurs, tibial squatting facet, talar squatting 
facet, and anterior calcaneal facets) were recorded when present. The analysis of pathological conditions and trauma was based on descriptive evaluation of abnormal bone appearance. Whenever possible, the following conditions were recorded as present (1) or absent (0): Cribra orbitalia, porotic hyperostosis, osteoperiostitis, degenerative joint disease (DJD; including vertebrae), enthesophytes/osteophytes, and laminal spurs along with the general appearance of abnormal bone structures based on the description of Steckel, Larsen, Sciulli, and Walker (2011) and Mann and Hunt (2005). If present, signs of healing were recorded as well.

\subsection{Caries intensity and tooth wear}

Teeth were evaluated individually due to the high amount of teeth without context. The following information was recorded (modified after Buikstra \& Ubelaker, 1994): type of tooth, root residues, dental wear, associated age, and the absence or presence of caries. Only root residues with clear signs of caries were recorded as being carious. Linear enamel hypoplasia and calculus were not recorded due to the inadequate preservation.

Due to the large amount of single teeth, only the caries intensity for permanent teeth (number of infected teeth/total number of observable teeth $\times 100$ ) was calculated including and excluding root residues (for comparison reasons), and teeth lost ante-mortem could not be considered (Stloukal, 1963).

Tooth wear of the permanent molars was recorded after Brothwell (1981), and only full stages were applied. The average stage of wear was calculated for M1, M2, M3, and not definable molars, because many molars could not be classified confidently.

\section{Results}

Over 2,000 bone fragments including only 83 complete ( $>75 \%$ of the bone present) long bones, mandibles, atlas, and axis were recovered (Table 1). No complete individual could be observed, neither in situ nor later reassembled in the laboratory. All bones of the human skeleton are present with various frequencies (Figure 3).

\subsection{Biological profile}

Femora as the most often occurring bony element (Figure 3) were used to evaluate the MNI and age-atdeath distribution of the individuals (Table 2). The evaluated features were greater and lesser trochanter, femoral caput and neck, and medial and lateral condyles. For nonadults, the size and development of diaphysis and epiphyses were considered.

All defined age categories are present: neonate 2\% (1/42), Infans I 5\% (2/42), Infans II 19\% (8/42), juvenile $17 \%$ (7/42), and adults 57\% (24/42; see Table 2). There was a nearly equal distribution of adult to subadult individuals ( $57 \%$ vs. $43 \%$, respectively). The majority of nonadults are present in category Infans II (19\%) followed by juvenile individuals (17\%), whereas Infans I, including neonate individuals, account for only $7 \%$. Similar patterns were observed for other skeletal elements, such as humeri, clavicles, and the first permanent molars.

Based on mandibles, 25\% (4/16) males, 31\% (5/16) females, 31\% (5/16) indeterminate (id) adults, and $13 \%(2 / 16)$ subadults were assessed. The aDNA analysis of the partes petrosae shows $44 \%(10 / 23)$ males, $35 \%(8 / 23)$ females, and 22\% (5/23) id individuals.

Three femora could be measured for stature estimation (Table 3 ). The sex was id, and the stature average ranges from 154 to $157 \mathrm{~cm}$ (Table 3, Table S1).

\subsection{Anatomical variations, pathological alterations and trauma}

Due to the overall insufficient bone preservation nonmetric traits, pathological and traumatic alterations were documented but could not be statistically evaluated. Several anatomical variations were observed: one Inca bone, three rhomboid fossae, two septal apertures, one spina bifida, one squatting facet, and 
three third trochanter.

The following pathological alterations could be documented: Cribra orbitalia, porotic hyperostosis, endocranial depressions, inflammation with cloaca, periosteal reactions, DJD, enthesophytes/osteophytes, laminal spurs, fusion of vertebral bodies or arches, Schmorl's depressions, and wedged shaped vertebral bodies. A few specific cases of pathological alterations were observed: a severe osteomyelitis (inflammation with cloaca formation) on femur OB 125474-1 (Figure 4a); a possible case of Morbus Scheuermann with two wedge shaped vertebral bodies in combination with Schmorl's depressions from a juvenile individual (OB 125003); a possible case of an ossified subperiosteal hematoma (OB 125016); a pronounced case (Stage 3) of DJD on scapula OB 126653; and a pronounced osteophyte formation (OB 125016; Figure 4b) as well as degeneration of superior and inferior facets of vertebrae (OB 126653; OB 127183) belonging to Stages 2-3 (Steckel et al., 2011). In general, musculoskeletal stress markers on long bones and patellae were noticed, too.

Four bones showed signs of healed fractures: clavicle fragment OB 125008 (Figure 4c), radius and ulna fragments OB 126650 (fusion of ulna and radius), fifth lumbar vertebra OB 125003 (stress fracture), and rib fragment OB 125127.

\subsection{Caries intensity and tooth wear}

In total, 726 teeth including deciduous teeth $(n=96)$ and root residues $(n=12)$ were investigated. The caries intensity is 8.3\% (52/630) including root residues and 7.9\% (49/618) excluding root residues. The average tooth wear of molar classes declines from M1 to M3: M1 = 2.4 (75/245); M2 = 2.2 (52/245); and M3 = $1.5(40 / 245)$.

\section{Discussion}

Working with commingled remains, the morphological analyses become challenging and prone to methodical bias depending on the degree of fragmentation and disturbances (Mack et al., 2016). The skeletal remains from Oberbipp were subjected to taphonomic changes indicated by the low number of complete larger bones $(n=83$; MNI 42). Hence, the absence or underrepresentation of sex or age categories and pathologies or trauma is limited by preservation.

\subsection{Burial practice}

During the third millennium BCE in Switzerland individuals were buried in extended supine and crouched position or were cremated. Limb bending is described for dolmen MXII at Sion Petit Chasseur in the southwest (Stöckli et al., 1995). Other examples for crouched inhumations derive from the wooden dolmen of Spreitenbach ( 2500 BCE) (Doppler, 2012). For Oberbipp, an extended supine position with some lower limb bending of a few individuals is observed. The challenge of verifying burial positions when dealing with commingled remains comes in addition to the fact that dolmen were intended to be collective burials and therefore are associated with relocation and fragmentation of bones (Mack et al., 2016). Sex-specific burial sides or positions have not been found in megalithic dolmen, such as postulated for Oberbipp (Figure 5, discussed below).

\subsection{Preservation and representation}

Based on the skeletal elements recovered, a primary deposition site is postulated, as bones from the entire human skeleton are present (Figure 3). Especially the presence of small bones such as carpals and phalanges indicates this, because they are mainly absent at secondary deposition sites due to relocation of the bodies at various stages of decomposition (Roksandic, 2002). The presence of small bones (Figure 3) also indicates that intruding water might not have had a severe effect on the human remains, as a bigger loss of the small skeletal elements would be expected.

However, the variation in the quantities of skeletal elements found can be attributed to the individual bone structures, because more dense and compact bones, such as the femora, are preserved more 
frequently than fragile bones, such as the viscerocranium (Figure 3; Mack et al., 2016; Manifold, 2015). Additionally, fragile bones might not be underrepresented rather than being unnoticed as such, due to their degree of fragmentation and therefore being recorded as indeterminable. In general, taphonomy, animal activity, later burials, and flooding contributed to a certain destruction of skeletal elements. The evaluation of the MNI and an age-at-death assessment is there- fore challenging. The MNI of 42 individuals is similar to other Middle to Late Neolithic collective burials (Table 4) from Western Europe(Alt et al., 2016; Fernández-Crespo \& de-la-Rúa, 2015; Mack et al., 2016; Silva, 2003; Steuri, 2017; Watermann \& Thomas, 2011) even though the number of individuals can vary greatly from site to site. The grave type (e.g., simple dolmen or passage tomb) and demographic factors certainly played a role how a collective grave was used. Unfortunately, comparable anthropological radiocarbon data are often unavailable, as for most of the 41 dolmen in the wider geographical region around Oberbipp (Schwegler, 2016; Steuri, 2017).

\subsection{Age distribution}

The presence of all age categories from neonate to mature and possibly senile individuals (based on degeneration and obliteration of cranial sutures) could be observed in Oberbipp and is also described for other Swiss (Meyer \& Alt, 2012), Spanish (Fernández-Crespo \& de-la-Rúa, 2015), and Greek (Papathanasiou, 2005) Neolithic burials. Adult individuals outnumber subadult individuals slightly, which is often seen for Neolithic multiple burials (Fernández-Crespo \& de-la- Rúa, 2015; Manifold, 2015; Watermann \& Thomas, 2011). In addition, the average molar wear also indicates a population structure with a larger amount of Infans II to young adults, $\leq 35$ years of age (Figure S1). Overall, this is in concordance with the anthropological results of the bones. However, a probable underrepresentation of Infans I at Oberbipp is observed, which is also seen at other sites such as Spreitenbach (Mack et al., 2016; Meyer \& Alt, 2012; Wahl \& Trautmann, 2012). Reasons could be taphonomic alterations and biased evaluation due to fragmentation (Chamberlain, 2006; Manifold, 2015). Also, animal respectively human activity and intruding water should be considered as potential causes of immature bone loss in our case, as immature bones are smaller and lighter and therefore probably more prone to those influences. Another reason may be that (very) young children received different burials, such as special places apart from the rest of the community and can therefore be virtually absent from a skeletal assemblage (Manifold, 2015; Watermann \& Thomas, 2011). In relation to the assumed lack of Infans I, the number of Infans II and juveniles appears to be relatively high. As the mortality of individuals of these age classes is expected to be lower under nor- mal circumstances, possible reasons could be epidemic or warlike events. However, we do not have evidence of perimortem violence on the bones. Even though, a few arrowheads were recovered from the dolmen (Ramstein et al., 2014); nevertheless, they were not found in association with any bone lesions. Therefore, an interpretation as grave goods rather than artefacts of violence seems to be more likely. In addition, the burial construction of a dolmen differs from mass graves such as Talheim or Halberstadt (Meyer et al., 2018; Wahl \& Trautmann, 2012). In future, aDNA results might provide information about pathogens, which could have caused the death of some individuals. A further factor to consider while searching for the causes of death is that the dolmen was used for several generations, based on radiocarbon dating (Steuri et al., submitted) and aDNA analysis (Furtwängler et al., in preparation).

\subsection{Sex distribution}

The fact that males outnumber females as seen by our aDNA sex determination can be stated for several Neolithic sites from Switzer- land and Spain (Table 4). But considering the method and the bone elements used, the ratios vary slightly at Oberbipp. Nonetheless, the result of the morphological sex evaluation should be interpreted with care as the sample size is too small $(n=16)$ to be representative for a MNI of 42. Based on our general data, an equal funerary treatment for men and women, at least for the location, is postulated. However, it seems that there was a trend of placing men and women at different sides in the dolmen. Females might have been mainly buried on the left hand side (southwest) and males on the right hand side (northeast) both with their heads towards the entrance (Figure 5). Further dolmen burials have to be assessed regarding this question and to verify or falsify the 
observation. Geber, Hensey, Meehan, Moore, and Kador (2017) discussed the possibility that females and subadults were cremated more frequently than men, but there are no burned remains found in Oberbipp. However, it would be crucial to verify these observations for future excavated dolmen burials. Regional differences in the burial practices have to be kept in mind as well, and it has to be remembered that dolmen are supposedly diachronic burial sites. A change in burial rites could have occurred during its use, which would hinder the interpretation of sex-specific burial practices.

\subsection{Health of the individuals}

The presence of oral pathologies such as carious lesions is often used as a proxy for the state of health and the nutrition of a population, especially the amount of carbohydrates in the diet (Subirà, LópezOnaindia, \& Yll, 2016). For the Neolithic period, a correlation between the increased carbohydrate intake and an increase in carious lesions can be observed (Eshed, Gopher, \& Hershkovitz, 2006; Richards, 2002). Based on the evaluation of the teeth from Oberbipp and a comparison with other Neolithic sites, it can be claimed that the Swiss series seem to have an increased caries intensity compared with populations from Central Europe (Table 5; Bock \& Bruchhaus, 2003; Meyer \& Alt, 2012; Nicklisch et al., 2016). Explanations could be a greater amount of carbohydrates in the diet, a different way of processing food, and a genetic predisposition for caries infections as discussed by Meyer and Alt (2012) and Subirà et al. (2016). This might be further discussed when associated aDNA and stable isotope results are available.

It can be stated that nonmetric anatomical variations, diseases, stress related alterations, and periosteal reactions along with other pathologies were present at Oberbipp. This is in concordance with studies by Alt et al. (2016), Papathanasiou (2005), and Verna and Villotte (2016) from Neolithic sites. Healed bone fractures (Figure 4c) and the severe case of osteomyelitis (Figure 4a) indicate that the individuals from Oberbipp lived in a society with some degree of caring because those individuals most likely required help for their everyday life (Milella, Zollikofer, \& Ponce de León, 2015).

Based on the level of fragmentation, no indications for perimortem trauma (due to interpersonal violence or accidents) could be observed on the skeletal elements. However, the studies by Madden, Karsten, Ledogar, Schmidt, and Sokhatsky (2018), Nicklisch et al. (2018), and Wierer et al. (2018) indicate that violence was quite existent during the Late Neolithic.

\section{Conclusion}

Switzerland is well known for its Neolithic pile dwelling sites. In contrast to this, there are hardly any human remains systematical osteologically investigated. Therefore, the inhumations from the dolmen of Oberbipp represent a unique opportunity to gain a better understanding of these populations. The population is represented by at least 42 individuals of all age classes, both sexes, average stature, and only few pathological alterations and trauma. It is likely that all age groups were treated equally with regard to burial customs, except (very) young individuals. The deceased were most probably placed in extended supine position with their heads towards the entrance with men mainly buried on the northeast and women on the southwest side of the chamber. This study has been the starting point for further bioarchaeological research on Late Neolithic farmers from Switzerland.

\section{Acknowledgements}

The morphological analyses of the skeletal remains were funded by the Swiss National Science Foundation (CR31I3L_157024), and the paleogenetic analyses were funded by the German Research Foundation (KR4015/4-1).

Special thanks go to the Archaeological Service of the Canton of Bern, Switzerland, for providing the material and supporting the study. 


\section{References}

Allentoft, M. E., Sikora, M., Sjögren, K.-G., Rasmussen, S., Rasmussen, M., Stenderup, J., ... Willerslev, E. (2015). Population genomics of Bronze Age Eurasia. Nature, 522, 167-172. https://doi.org/10.1038/nature14507

Alt, K. W., Zesch, S., Garrido-Pena, R., Knipper, C., Szécsényi-Nagy, A., Roth, C., ... Rojo-Guerra, M. A. (2016). A community in life and death: The Late Neolithic megalithic tomb at Alto de Reinoso (Burgos, Spain). Plos One, 11(1), 1-32. e0146176. https://doi.org/10.1371/journal. pone.0146176

Bay, R. (1936). Kiefer und Zähne aus dem neolithischen Steinkistengrab bei Aesch. Tätigkeitsbericht der Naturforschenden Gesellschaft Baselland, 11(1936-1938), 22-30.

Bickle, P., Arbogast, R. M., Bentley, R. A., Fibiger, L., Hamilton, J., Hedges, R., \& Whittle, A. (2013). Alsace. In P. Bickle, \& A. Whittle (Eds.), The first farmers of Central Europe-Diversity in LBK lifeways (pp. 291-340). Oxford and Oakville: Oxbow Books.

Bickle, P., Bentley, R. A., Blesl, C., Fibiger, L., Hamilton, J., Hedges, R., ... Whittle, A. (2013). Austria. In P. Bickle, \& A. Whittle (Eds.), The first farmers of Central Europe-Diversity in LBK lifeways (pp. 159-202). Oxford and Oakville: Oxbow Books.

Bickle, P., \& Whittle, A. (Eds.) (2013). The first farmers of Central Europe- Diversity in LBK lifeways. Oxford and Oakville: Oxbow Books.

Bock, S., \& Bruchhaus, H. (2003). Karies in ausgewählten prähistorischen und historischen Populationen des Mittelelbe-Saale-Gebietes - Gab es Geschlechtsunterschiede? Bulletin der Schweizerischen Gesellschaft für Anthropologie, 9(1), 7-22.

Brothwell, D. R. (1981). Digging up bones. The excavation, treatment and study of human skeletal remains (3rd ed.). Oxford: Oxford University Press.

Buikstra, J. E., \& Ubelaker, D. H. (1994). Standards for data collection from human skeletal remains: Proceedings of a seminar at the Field Museum of Natural History, organised by Jonathan Haas (Vol. 44). Fayetteville, Arkansas: Arkansas Archeological Survey.

Chamberlain, A. C. (2006). Demography in archaeology. Cambridge: Cam- bridge University Press. https://doi.org/10.1017/CBO9780511607165

Dabney, J., Knapp, M., Glocke, I., Gansauge, M.-T., Weihmann, A., Nickel, B., ... Meyer, M. (2013). Complete mitochondrial genome sequence of a Middle Pleistocene cave bear reconstructed from ultrashort DNA fragments. Proceedings of the National Academy of Sciences, 110(39), 15758-15763. https://doi.org/10.1073/pnas.1314445110

Doppler, T. (Ed.) (2012). Spreitenbach-Moosweg (Aargau, Schweiz): Ein Kollektivgrab um 2500 v. Chr. Basel: Archäologie Schweiz.

Eshed, V., Gopher, A., \& Hershkovitz, I. (2006). Tooth wear and dental pathology at the advent of agriculture: New evidence from the Levant. American Journal of Physical Anthropology, 130(2), 145159. https:// doi.org/10.1002/ajpa.20362

Fernández-Crespo, T., \& de-la-Rúa, C. (2015). Demographic evidence of selective burial in megalithic graves of northern Spain. Journal of Archaeological Science, 53, 604-617. https://doi.org/10.1016/j. jas.2014.11.015 
Furtwängler, A., Reiter, E., Neumann, G. U., Siebke, I., Steuri, N., Hafner, A.,... Krause, J. (2018). Ratio of mitochondrial to nuclear DNA affects contamination estimates in ancient DNA analysis. Scientific Reports, 8(1), 14075. https://doi.org/10.1038/s41598-018-32083-0

Furtwängler, A., Reiter, E., Neumann, G. U., Siebke, I., Steuri, N., Hafner, A.,... Krause, J. (in preparation). Ancient genomes reveal parallel societies in Late Neolithic Switzerland.

Geber, J., Hensey, R., Meehan, P., Moore, S., \& Kador, T. (2017). Reassessing the age, sex and metric variation of commingled human remains from a 1911 excavation of a Neolithic passage tomb complex in North-West Ireland. International Journal of Osteoarchaeology, 27(2), 131-142. https://doi.org/10.1002/oa.2521

Haak, W., Balanovsky, O., Sanchez, J. J., Koshel, S., Zaporozhchenko, V., Adler, C. J., ... Consortium, G. (2010). Ancient DNA from European Early Neolithic farmers reveals their near eastern affinities. Plos Biology, 8(11), e1000536. https://doi.org/10.1371/journal.pbio.1000536

Haak, W., Lazaridis, I., Patterson, N., Rohland, N., Mallick, S., Llamas, B., ... Reich, D. (2015). Massive migration from the steppe was a source for Indo-European languages in Europe. Nature, 522(7555), 207-211. https://doi.org/10.1038/nature14317

Hafner, A., \& Suter, P. (2003). Das Neolithikum in der Schweiz. Journal of Neolithic Archaeology. https://doi.org/10.12766/jna.2003.4

Kircher, M., Sawyer, S., \& Meyer, M. (2012). Double indexing overcomes inaccuracies in multiplex sequencing on the Illumina platform. Nucleic Acids Res, 40(1), e3. https://doi.org/10.1093/nar/gkr771

Mack, J. E., Waterman, A. J., Racila, A. M., Artz, J. A., \& Lillios, K. T. (2016). Applying zooarchaeological methods to interpret mortuary behavior and taphonomy in commingled burials: The case study of the Late Neo- lithic site of Bolores, Portugal. International Journal of Osteoarchaeology, 26(3), 524-536. https://doi.org/10.1002/oa.2443

Madden, G., Karsten, J., Ledogar, S., Schmidt, R., \& Sokhatsky, M. (2018). Violence at Verteba Cave, Ukraine: New insights into the Late Neo- lithic intergroup conflict. International Journal of Osteoarchaeology, 28(1), 44-53. https://doi.org/10.1002/oa.2633

Manifold, B. M. (2015). Skeletal preservation of children's remains in the archaeological record. HOMO - Journal of Comparative Human Biology, 66(6), 520-548. https://doi.org/10.1016/j.jchb.2015.04.003

Mann, R. W., \& Hunt, D. R. (2005). Photographic regional atlas of bone disease: A guide to pathologic and normal variation in the human skeleton. Springfield, Illinois: Charles C Thomas.

Martin, R. (1914). Lehrbuch der Anthropologie in systematischer Darstellung mit besonderer Berücksichtigung der anthropologischen Methoden. Jena: Gustav Fischer.

Meyer, C., \& Alt, K. W. (2012). Anthropologische Untersuchung der menschlichen Skelettfunde aus dem endneolithischen Kollektivgrab von Spreitenbach: osteologischer Individualbefund und Populationscharakteristik. In T. Doppler (Ed.), Spreitenbach-Moosweg (Aargau, Schweiz): Ein Kollektivgrab um 2500 v. Chr. (-104, 157). Basel: Urs Zuber AG.

Meyer, C., Knipper, C., Nicklisch, N., Münster, A., Kürbis, O., Dresely, V., ... Alt, K. W. (2018). Early Neolithic executions indicated by clustered cra- nial trauma in the mass grave of Halberstadt. Nature Communications, 9(1), 2472. https://doi.org/10.1038/s41467-018-04773-w

Meyer, M., \& Kircher, M. (2010). Illumina sequencing library preparation for highly multiplexed target capture and sequencing. Cold Spring Harb Protoc, 2010(6). https://doi.org/10.1101/pdb.prot5448 
Milella, M., Zollikofer, C. P. E., \& Ponce de León, M. S. (2015). A Neolithic case of mesomelic dysplasia from Northern Switzerland. International Journal of Osteoarchaeology, 25(6), 981-987. https://doi.org/10.1002/ oa.2390

Mittnik, A., Wang, C.-C., Svoboda, J., \& Krause, J. (2016). A molecular approach to the sexing of the triple burial at the Upper Paleolithic site of Dolní Věstonice. Plos One, 11(10), e0163019. https://doi.org/ 10.1371/journal.pone.0163019

Nicklisch, N., Dresely, V., Orschiedt, J., Ramsthaler, F., Schlenker, B., Ganslmeier, R., ... Alt, K. W. (2018). A possible case of symbolic trepanation in Neolithic Central Germany. International Journal of Osteoarchaeology, 28(3), 216-226. https://doi.org/10.1002/oa.2648

Nicklisch, N., Ganslmeier, R., Siebert, A., Friederich, S., Meller, H., \& Alt, K. W. (2016). Holes in teeth-Dental caries in Neolithic and Early Bronze Age populations in Central Germany. Annals of Anatomy - Anatomischer Anzeiger, 203, 90-99. https://doi.org/10.1016/j. aanat.2015.02.001

Osterholtz, A. J., Baustian, K. M., Martin, D. L., \& Potts, D. T. (2014). Commingled human skeletal assemblages: Integrative techniques in determination of the MNI/MNE. In A. J. Osterholtz, K. M. Baustian, \& D. L. Martin (Eds.), Commingled and disarticulated human remains (pp. 35-50). New York: Springer-Verlag. https://doi.org/10.1007/ 978-1-4614-7560-6_3

Palafittes, S. c. G. U. (2015). UNESCO world heritage-Prehistory pile dwelling around the Alps. Retrieved from http://sites.palafittes.org/home.

Papathanasiou, A. (2005). Health status of the Neolithic population of Alepotrypa Cave, Greece. American Journal of Physical Anthropology, 126(4), 377-390. https://doi.org/10.1002/ajpa.20140

Pearson, K. (1899). Mathematical contributions to the theory of evolution. V. On the reconstruction of the stature of prehistoric races. Philosophical Transactions of the Royal Society of London, 192, 169244. https:// doi.org/10.1098/rsta.1899.0004

Peltzer, A., Jager, G., Herbig, A., Seitz, A., Kniep, C., Krause, J., \& Nieselt, K. (2016). EAGER: Efficient ancient genome reconstruction. Genome Biol, 17, 60. https://doi.org/10.1186/s13059-0160918-z

Ramstein, M., Schimmelpfennig, D., \& Lösch, S. (2014). Ein neolithischer Dolmen an der Steingasse in Oberbipp. Archäologie Schweiz, 37(3), 4-15.

Richards, M. P. (2002). A brief review of the archaeological evidence for Palaeolithic and Neolithic subsistence. European Journal of Clinical Nutrition, 56, 1270-1278. https://doi.org/10.1038/sj.ejcn.1601646

Roksandic, M. (2002). Position of skeletal remains as a key to understand- ing mortuary behavior. In W. D. Haglund, \& M. H. Sorg (Eds.), Advances in forensic taphonomy: Method, theory, and archaeological perspectives (pp. 99-117). Boca Raton: CRC Press.

Scheuer, L., \& Black, S. (2004). The juvenile skeleton. London, San Diego: Elsevier Academic Press.

Schwegler, U. (2016). Chronologie und Regionalität neolithischer Kollektivgräber in Europa und in der Schweiz. Hochwald: LIBRUM Publishers \& Editors LLC.

Siebke, I., Campana, L., Ramstein, M., Furtwängler, A., Hafner, A., \& Lösch, S. (2018). The application of different 3D-scan-systems and photo- grammetry at an excavation-A Neolithic dolmen from Switzerland. Digital Applications in Archaeology and Cultural Heritage, 10, e00078. https://doi.org/10.1016/j.daach.2018.e00078 
Siebke, I., Furtwängler, A., Steuri, N., Hafner, A., Ramstein, M., Krause, J., \& Lösch, S. (in preparation). Insights into Late and Final Neolithic diets - Stable isotope analysis of Neolithic farmers from Switzerland.

Silva, A. M. (2003). Portuguese populations of Late Neolithic and Chalcolithic periods exhumed from collective burials: An overview. Anthropologie, 41(1-2), 55.

Sjøvold, T. (1988). Geschlechtsdiagnose am Skelett. In R. Knussmann (Ed.), Anthropologie: Handbuch der vergleichenden Biologie des Menschen (pp. 444-480). Stuttgart, New York: Gustav Fischer Verlag.

Skoglund, P., Northoff, B. H., Shunkov, M. V., Derevianko, A. P., Pääbo, S., Krause, J., \& Jakobsson, M. (2014). Separating endogenous ancient DNA from modern day contamination in a Siberian Neandertal. Proceed- ings of the National Academy of Sciences of the United States of America, 111(6), 2229-2234. https://doi.org/10.1073/pnas.1318934111

Steckel, R., Larsen, C., Sciulli, P., \& Walker, P. (2011). The global history of health project: Data collection codebook (Revised January 10, 2011 ed.). Columbus, OH: Ohio State University.

Steuri, N. (2017). Der Dolmen von Oberbipp - Archäologische Auswertung eines neolithischen Kollektivgrabes. (Master Thesis), University of Bern, unpublished.

Steuri, N., Siebke, I., Furtwängler, A., Brunner, M., Szidat, S., Krause, J., . . . Hafner, A. (submitted). Multiple radiocarbon dating of human remains: Clarifying the chronology and sequences of burials in the Late Neolithic dolmen of Oberbipp (Switzerland).

Stloukal, M. (1963). Der Gesundheitszustand des Gebisses bei der Population von Grossmährischen Mikulčice. Anthropologie, 1, 35-45.

Stöckli, W. E., Niffeler, U., \& Gross-Klee, E. (Eds.) (1995). Neolithikum - Néolithique - Neolitico. Basel: SPM II.

Subirà, M. E., López-Onaindia, D., \& Yll, R. (2016). Cultural changes in funeral rites during the Neolithic in the northeast of the Iberian Peninsula? The Cave of Pantà de Foix (Barcelona). International Journal of Osteoarchaeology, 26(1), 104-113. https://doi.org/ 10.1002/oa.2400

Verna, E., \& Villotte, S. (2016). Several infra-cranial non-metric variations in a single Neolithic individual: A common genetic underlying predisposition? International Journal of Osteoarchaeology, 26(6), 1113-1118. https://doi.org/10.1002/oa.2522

Wahl, J., \& Trautmann, I. (2012). The Neolithic massacre at Talheim: A piv- otal find in conflict archaeology. In R. J. Schulting, \& L. Fibiger (Eds.), Sticks, stones, and broken bones: Neolithic violence in a European perspective (pp. 77-100). Oxford University Press. https://doi.org/10.1093/ acprof:osobl/9780199573066.003.0005

Watermann, A. J., \& Thomas, J. T. (2011). When the bough breaks: Child- hood mortality and burial practice in Late Neolithic Atlantic Europe. Oxford Journal of Archaeology, 30(2), 165-183. https://doi.org/ 10.1111/j.1468-0092.2011.00363.x

White, T. D., Black, M. T., \& Folkens, P. A. (2012). Human osteology (3rd ed.). Burlington; San Diego; Oxford: Elsevier Academic Press.

Wierer, U., Arrighi, S., Bertola, S., Kaufmann, G., Baumgarten, B., Pedrotti, A., ... Pelegrin, J. (2018). The Iceman's lithic toolkit: Raw material, technology, typology and use. Plos One, 13(6), e0198292. https://doi.org/ 10.1371/journal.pone.0198292 
Wyss, R. (1998). Das neolithische Hockergräberfeld von Lenzburg, Kt. Aargau. In S. L. Zürich (Ed.). Archäologische Forschungen. Zürich: Schweizerisches Landesmuseum Zürich.

\section{Figures}

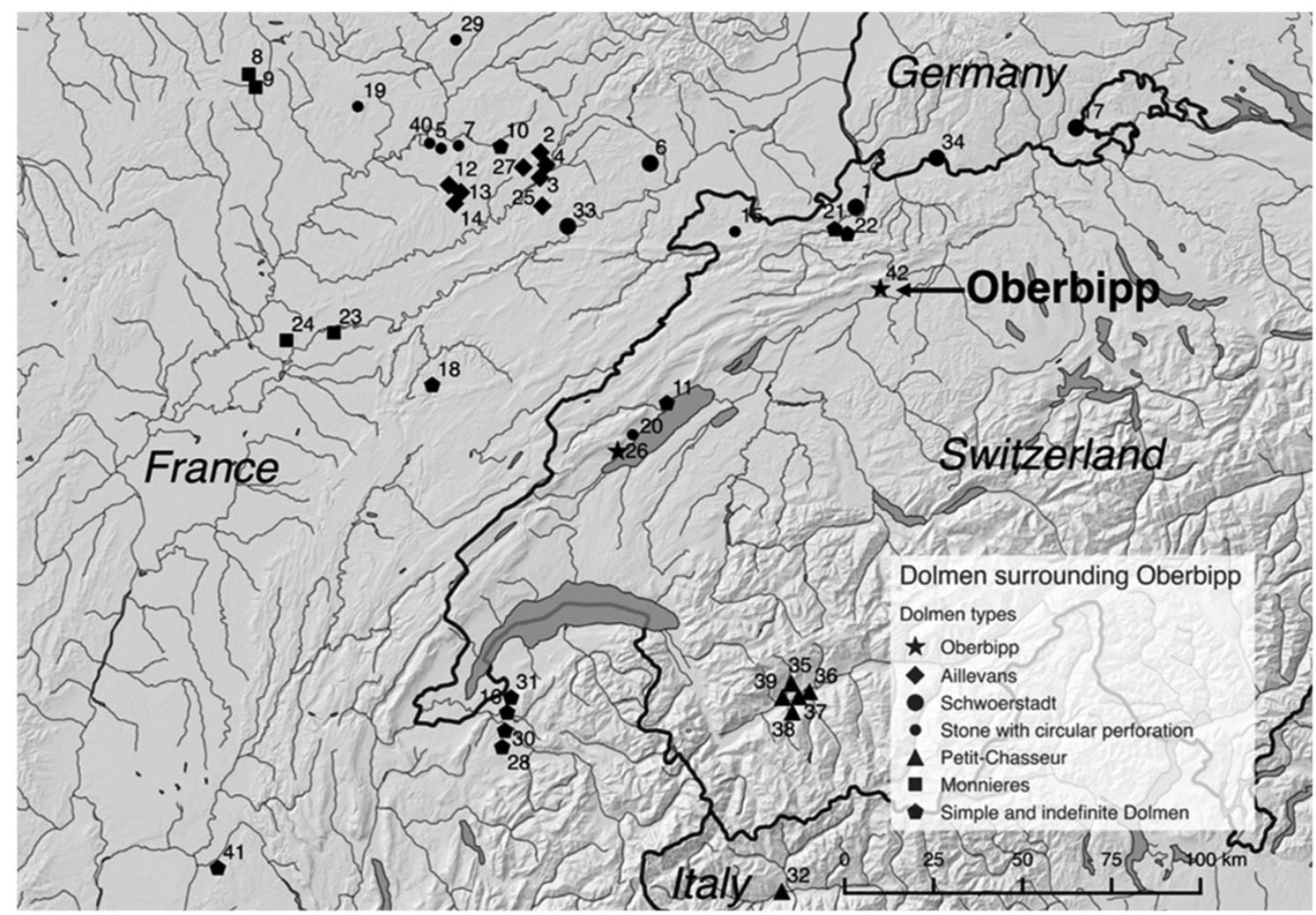

Figure 1: Dolmen with a distance of approximately $200 \mathrm{~km}$ to Oberbipp. 1. Aesch; 2. Aillevans 1; 3. Aillevans 2; 4. Aillevans 3; 5. Aroz; 6. Brévilliers; 7. Chariez; 8. Cohons 1; 9. Cohons 2; 10. Colombe-les-Vesoul; 11. Colombier (Auvernier); 12. Courboux-Pennessières 1; 13. Courboux-Pennessières 2; 14. Courboux-Pennessières 3; 15. Courgenay; 16. Cranves-Sales; 17. Degernau; 18. Échenloz-le-Sec; 19. Fouvent-le-Haut; 20. Fresens; 21. Laufen 1; 22. Laufen 2; 23. Lavans-lès-Dole (Moulin rouge); 24. Monnières (Mont Joly); 25. Mont-Roland (Cuse-etAdrisans); 26. Onnens; 27. Oppenans; 28. Pers-Jussy; 29. Polaincourt; 30. Reignier; 31. SaintCergues; 32. Saint-Martin de Corléans T. II; 33. Santoche; 34. Schwörstadt; 35. Sion PetitChasseur Dolmen MI; 36. Sion Petit-Chasseur Dolmen MV; 37. Sion Petit-Chasseur Dolmen MVI; 38. Sion Petit-Chasseur Dolmen MXI; 39. Sion Petit-Chasseur Dolmen MXII; 40. Traves; 41. Verna; 42. Oberbipp. 

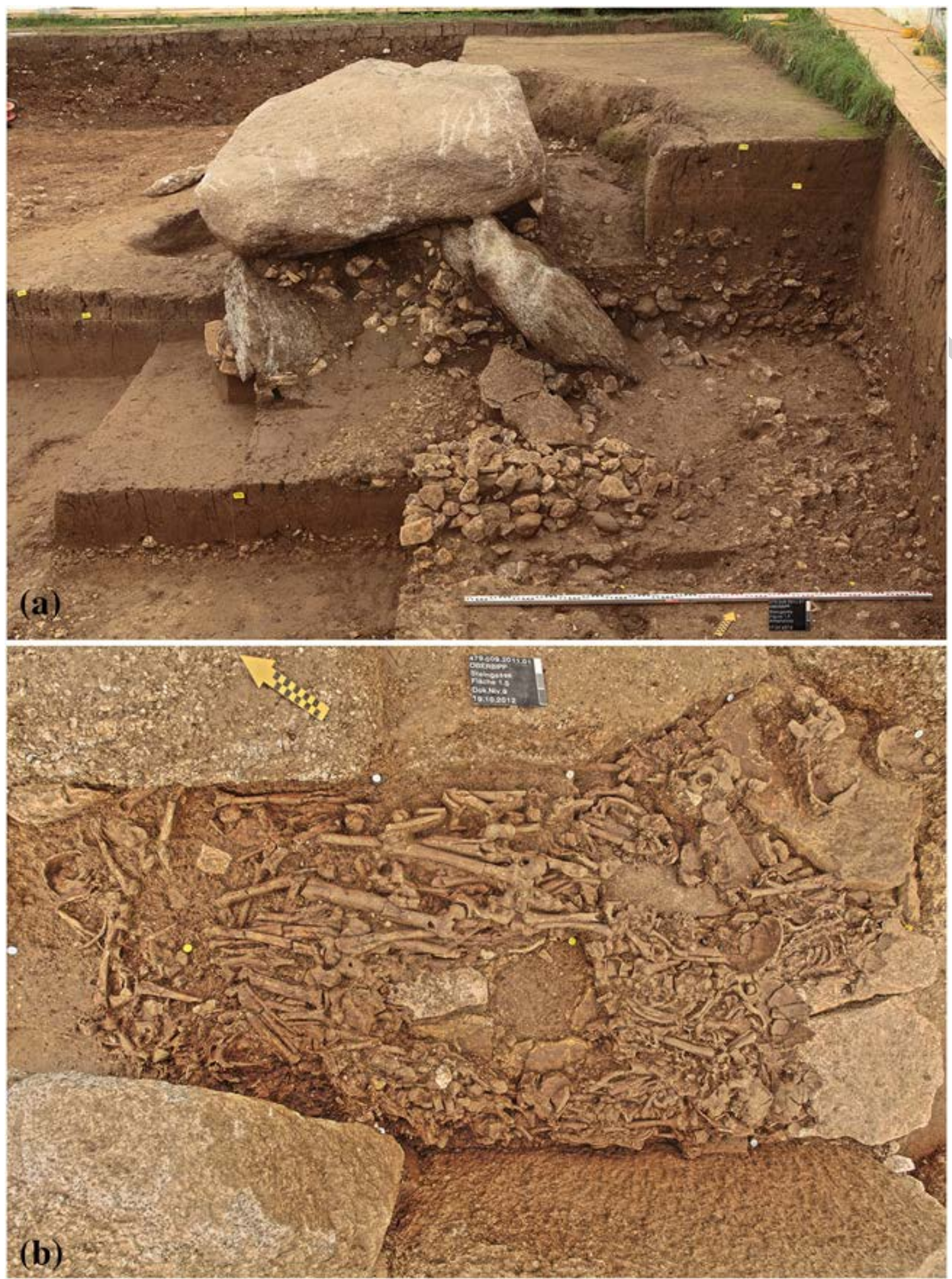

Figure 2: (a) The dolmen at the beginning of the excavation, view towards the entrance. (b) Alower layer of the human remains found in situ. 


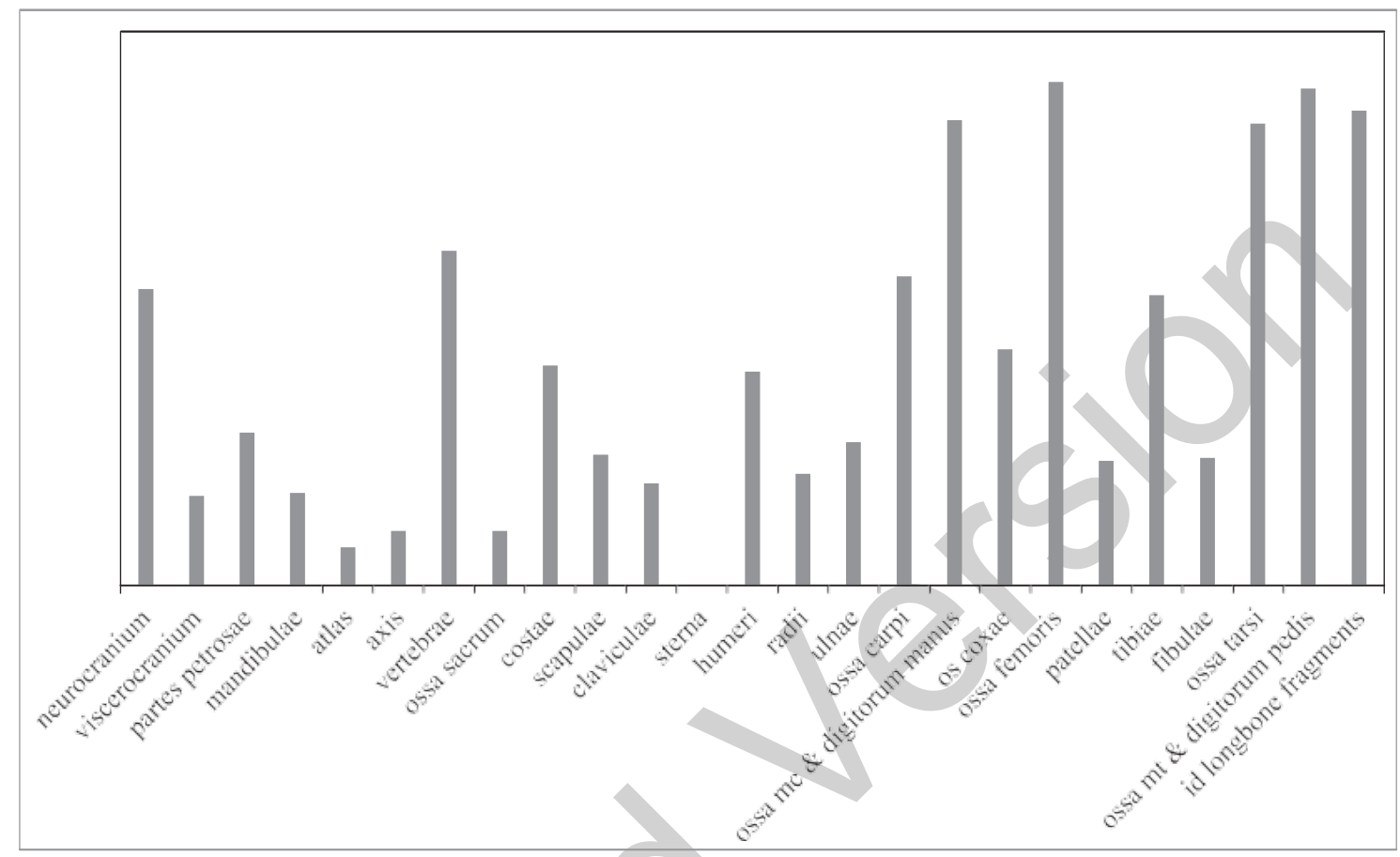

Figure 3: Distribution of minimum skeletal elements (MNE). Fragments of the same bone type were assumed to be one part when they had the same recovery number and no doubling was present. 

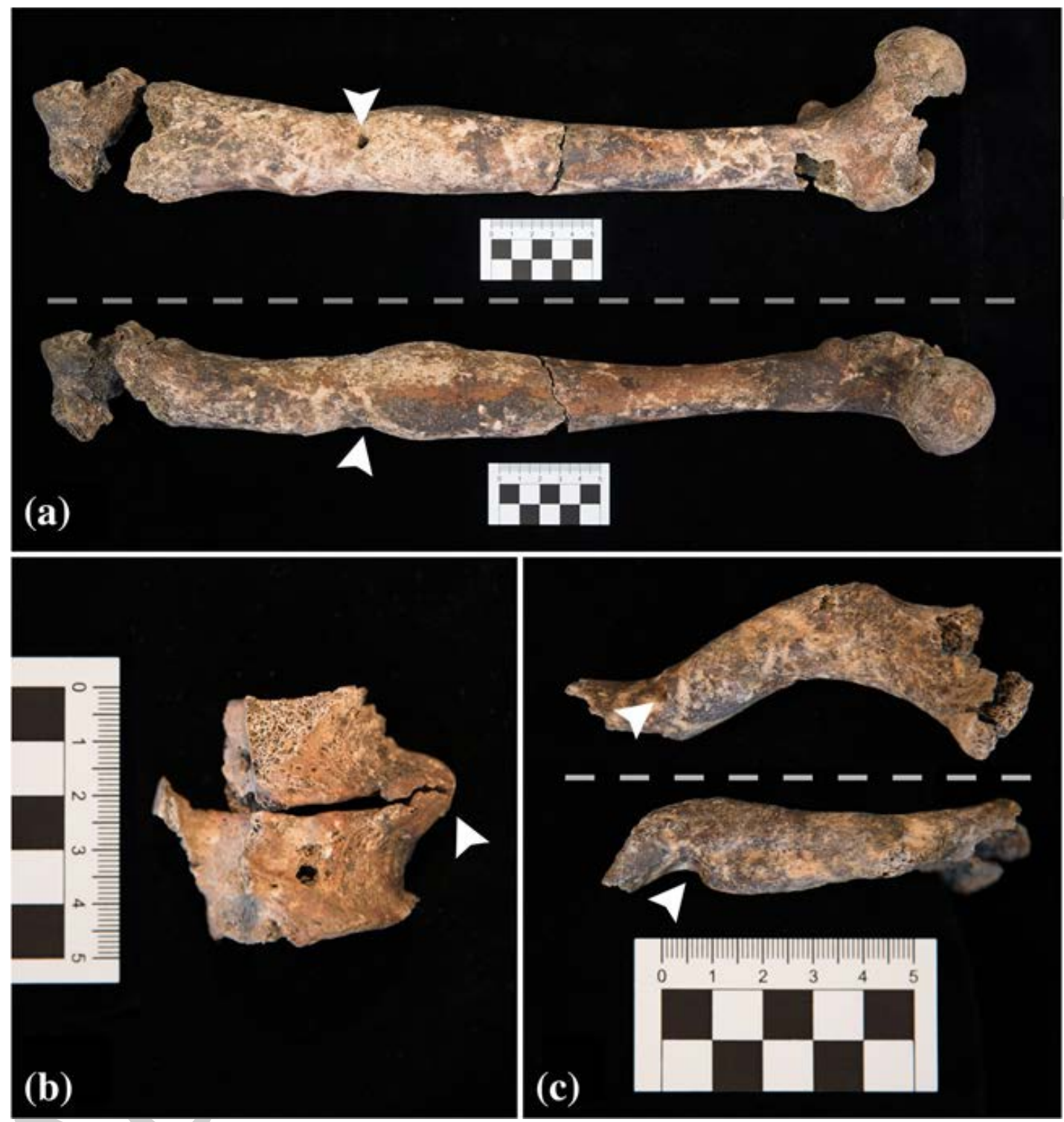

Figure 4: (a) Left femur with severe osteomyelitis and cloaca (upper: anterior view) and (lower: medial view). (b) Two thoracic vertebrae bodies with osteophytes anteriorly (lateral view). (c) Right clavicle fragment with complete but oblique healed fracture (upper: inferior view) and (lower: posterior view). 


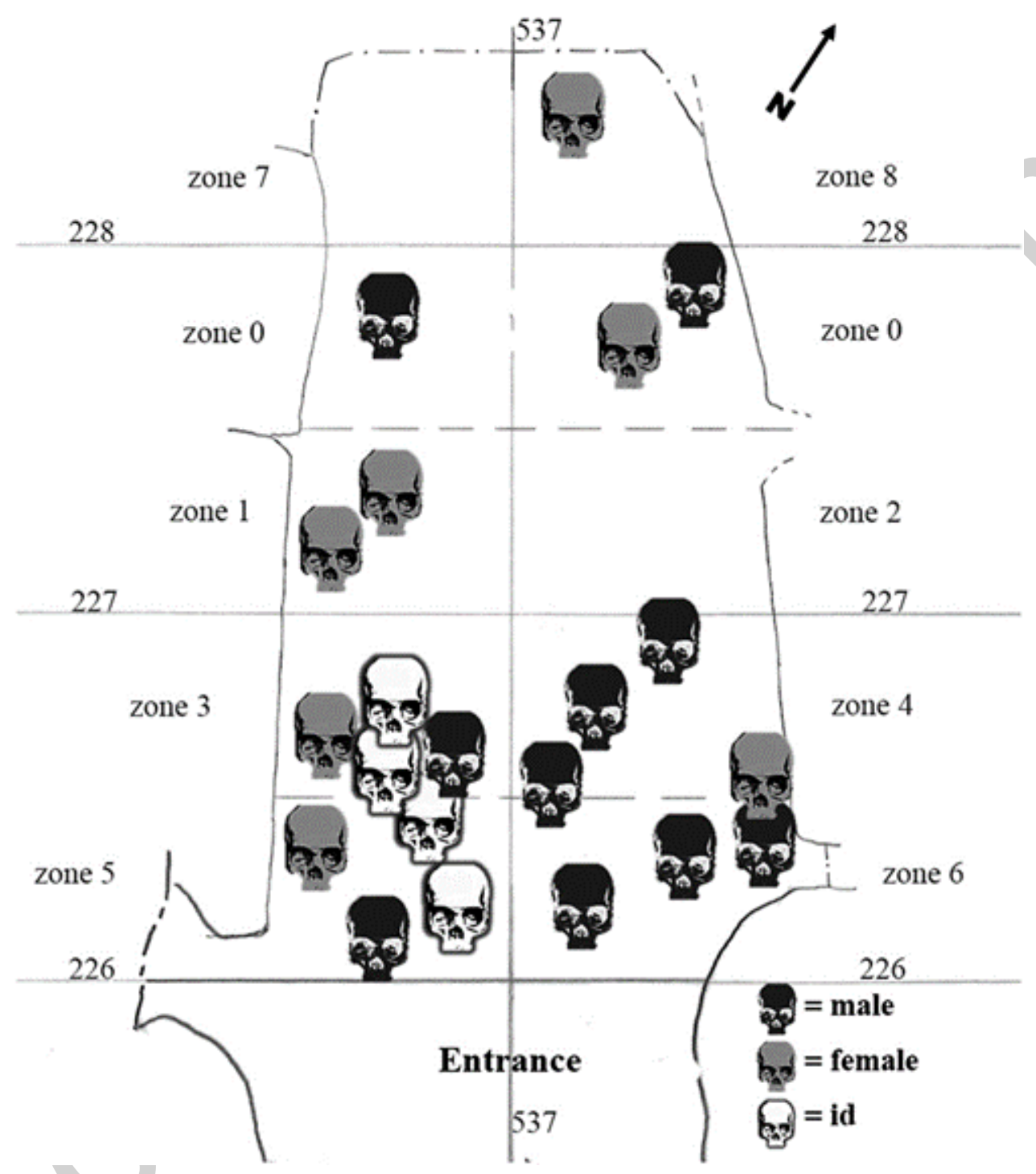

Figure 5: Sex distribution of adults within the dolmen, based on aDNA analysis of the partes petrosae. id, indeterminate. 


\begin{tabular}{|c|c|c|}
\hline $\begin{array}{c}\text { Skeletal } \\
\text { area }\end{array}$ & $\begin{array}{l}\text { Skeletal } \\
\text { Element }\end{array}$ & $\begin{array}{l}>75 \% \text { of } \\
\text { bone } \\
\text { complete }\end{array}$ \\
\hline Skull & mandibulae & 6 \\
\hline \multirow{3}{*}{ 离苞 } & ossa sacrum & 1 \\
\hline & atlas & 3 \\
\hline & axis & 6 \\
\hline \multirow{5}{*}{ 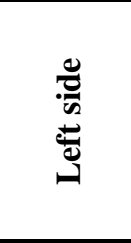 } & claviculae & 7 \\
\hline & humeri & 5 \\
\hline & ossa femoris & 4 \\
\hline & patellae & 13 \\
\hline & tibiae & 5 \\
\hline \multirow{7}{*}{ 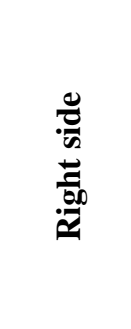 } & claviculae & 2 \\
\hline & humeri & 2 \\
\hline & radii & 1 \\
\hline & ulnae & 1 \\
\hline & ossa femoris & 8 \\
\hline & patellae & 14 \\
\hline & tibiae & 5 \\
\hline
\end{tabular}

\section{Tables}

Table 1: Presence of complete bones ( $>75 \%$ of the bone is present) sorted by skeletal element and side.

Table 2: Distribution of ossa femoris by side, proximal and distal fragments, and age categories.

\begin{tabular}{|l|c|c|c|c|}
\hline \multirow{2}{*}{ Age class } & \multicolumn{2}{|c|}{ Right os femoris } & \multicolumn{2}{c|}{ Left os femoris } \\
\cline { 2 - 5 } & prox. & distal & prox. & distal \\
\hline Adult & 24 & 19 & 13 & 14 \\
\hline Juvenile & 5 & 7 & 5 & 4 \\
\hline Infans II & $\mathbf{8}$ & 3 & 6 & 4 \\
\hline Infans I & $\mathbf{2}$ & 0 & 1 & 0 \\
\hline Neonate & 0 & 0 & 1 & 0 \\
\hline
\end{tabular}

Table 3: Stature estimation (cm) of complete femora. Stature was calculated for males and females individually based on Pearson's (1899) formulas, and results were combined as no sex could be assigned (id); *=Linea aspera was not pronounced; F1=maximum length of femora.

\begin{tabular}{|c|c|c|c|c|}
\hline sample & \multirow{2}{*}{ F1 } & \multicolumn{3}{|c|}{ combined stature (sex id) } \\
\cline { 3 - 5 } ID: OB & & $>$ height & $<$ height & average \\
\hline 125436* & 40.6 & 147.7 & 162.4 & 154.7 \\
\hline
\end{tabular}




\begin{tabular}{|l|l|l|l|l|}
\hline $125442 *$ & 41.8 & 150.0 & 164.7 & 157.0 \\
\hline 127152 & 40.0 & 146.5 & 161.3 & 153.6 \\
\hline
\end{tabular}

Table 4: The sex distribution at different Neolithic burial sites; id=indeterminate; MNI=minimum number of individuals; NA=not available.

\begin{tabular}{|c|c|c|c|c|c|c|c|c|c|c|c|c|}
\hline 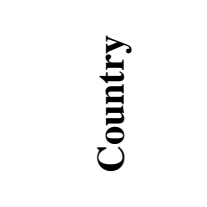 & 䒕 & 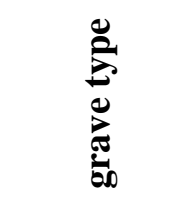 & 窇罢 & $\sum_{\Sigma}^{Z}$ & $\mathbf{I}$ & $\frac{\mathscr{U}}{\mathfrak{\Xi}}$ & 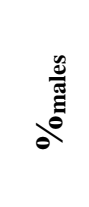 & 兽 & 选 & 픔 & 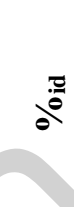 & 巡 \\
\hline Switzerland & Lenzburg & $\begin{array}{l}\text { stone } \\
\text { cists }\end{array}$ & $\begin{array}{l}4400- \\
4100\end{array}$ & 91 & 62 & 30 & 48 & 16 & 26 & 16 & 26 & $\begin{array}{l}\text { Schwegler, } \\
\text { (2016); } \\
\text { Wyss, } \\
(1998)\end{array}$ \\
\hline Switzerland & Oberbipp & dolmen & $\begin{array}{l}3350- \\
2650\end{array}$ & 42 & 25 & 11 & 44 & 10 & 40 & 4 & 16 & this study \\
\hline Switzerland & Aesch & dolmen & $\begin{array}{l}3100- \\
2500\end{array}$ & 47 & 25 & 14 & 56 & 10 & 40 & 1 & 4 & $\begin{array}{l}\text { Schwegler, } \\
\text { (2016); this } \\
\text { study }\end{array}$ \\
\hline Switzerland & Muttenz & $\begin{array}{l}\text { possible } \\
\text { dolmen }\end{array}$ & $\begin{array}{l}3000- \\
2700\end{array}$ & NA & 5 & 3 & 60 & 2 & 40 & 0 & 0 & unpublished \\
\hline Switzerland & Spreitenbach & $\begin{array}{l}\text { wooden } \\
\text { dolmen }\end{array}$ & $\begin{array}{l}\sim 2500 \\
\sim\end{array}$ & 12 & 12 & 6 & 50 & 4 & 33 & 2 & 17 & $\begin{array}{l}\text { Meyer \& } \\
\text { Alt, (2012) }\end{array}$ \\
\hline Spain & $\begin{array}{l}\text { Alto de } \\
\text { Reinoso }\end{array}$ & dolmen & $\sim 3700$ & 47 & 21 & 9 & 43 & 5 & 24 & 7 & 33 & $\begin{array}{l}\text { Alt et al., } \\
\text { (2016) }\end{array}$ \\
\hline Spain & La Cascaja & $\begin{array}{l}\text { passage } \\
\text { tomb }\end{array}$ & NA & 28 & 23 & 8 & 35 & 8 & 35 & 7 & 30 & $\begin{array}{l}\text { Fernández- } \\
\text { Crespo \& } \\
\text { de-la-Rúa, } \\
\text { (2015) }\end{array}$ \\
\hline Spain & San Martín & $\begin{array}{l}\text { passage } \\
\text { tomb }\end{array}$ & $\begin{array}{l}3700- \\
3400\end{array}$ & 22 & 19 & 9 & 47 & 4 & 21 & 6 & 32 & $\begin{array}{l}\text { Fernández- } \\
\text { Crespo \& } \\
\text { de-la-Rúa, } \\
\text { (2015) }\end{array}$ \\
\hline Spain & $\begin{array}{l}\text { Alto de la } \\
\text { Huesera }\end{array}$ & $\begin{array}{l}\text { passage } \\
\text { tomb }\end{array}$ & $\begin{array}{l}3400- \\
1800\end{array}$ & 106 & 81 & 29 & 36 & 27 & 33 & 25 & 31 & $\begin{array}{l}\text { Fernández- } \\
\text { Crespo \& } \\
\text { de-la-Rúa, } \\
(2015)\end{array}$ \\
\hline Spain & $\begin{array}{l}\text { Peña Guerra } \\
\text { II }\end{array}$ & $\begin{array}{l}\text { dolmen (2 } \\
\text { chambers) }\end{array}$ & $\begin{array}{l}3600- \\
1500\end{array}$ & 41 & 28 & 11 & 39 & 10 & 36 & 7 & 25 & $\begin{array}{l}\text { Fernández- } \\
\text { Crespo \& } \\
\text { de-la-Rúa, } \\
\text { (2015) }\end{array}$ \\
\hline Spain & $\begin{array}{l}\text { Collado del } \\
\text { Mallo }\end{array}$ & $\begin{array}{l}\text { passage } \\
\text { tomb }\end{array}$ & $\begin{array}{l}3700- \\
2000\end{array}$ & 31 & 20 & 10 & 50 & 5 & 25 & 5 & 25 & $\begin{array}{l}\text { Fernández- } \\
\text { Crespo \& } \\
\text { de-la-Rúa, } \\
(2015)\end{array}$ \\
\hline Spain & $\begin{array}{l}\text { Collado } \\
\text { Palomero I }\end{array}$ & dolmen & $\begin{array}{l}3600- \\
2000\end{array}$ & 12 & 9 & 0 & 0 & 1 & 11 & 8 & 89 & $\begin{array}{l}\text { Fernández- } \\
\text { Crespo \& } \\
\text { de-la-Rúa, } \\
(2015)\end{array}$ \\
\hline Spain & $\begin{array}{l}\text { Fuente } \\
\text { Morena }\end{array}$ & dolmen & $\begin{array}{l}3600- \\
3400\end{array}$ & 8 & 7 & 3 & 43 & 1 & 14 & 3 & 43 & $\begin{array}{l}\text { Fernández- } \\
\text { Crespo \& }\end{array}$ \\
\hline
\end{tabular}




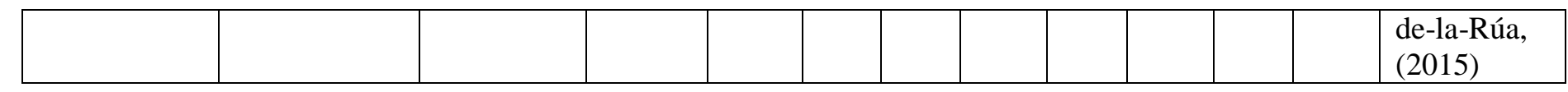

Table 5: Caries intensity (CI) excluding root residues for different Neolithic sites from Central Europe; *=young individuals; MES=Mittelelbe-Saale Region (region in Germany).

\begin{tabular}{|c|c|c|c|c|c|c|}
\hline Country & Site & $\begin{array}{l}\sim \text { Date } \\
\text { [BCE] }\end{array}$ & $\begin{array}{c}\mathbf{N}_{\text {Total }} \\
\text { teeth }\end{array}$ & $\begin{array}{c}\mathbf{n}_{\text {carious }} \\
\text { teeth }\end{array}$ & $\begin{array}{c}\text { CI } \text { Iexcl. }_{\text {. }} \\
\text { Roots }[\%]\end{array}$ & References \\
\hline France & Mulhouse-Est & $5500-4900$ & 156 & 6 & 3.8 & $\begin{array}{l}\text { Bickle et al., } \\
\text { (2013a) }\end{array}$ \\
\hline France & $\begin{array}{l}\text { Ensisheim les } \\
\text { Octrois }\end{array}$ & $5500-4900$ & 429 & 10 & 2.3 & $\begin{array}{c}\text { Bickle et al., } \\
\text { (2013a) }\end{array}$ \\
\hline Austria & Mitterndorf & $5500-4900$ & 347 & 9 & 2.6 & $\begin{array}{l}\text { Bickle et al., } \\
(2013 \mathrm{~b})\end{array}$ \\
\hline Austria & Rutzing & $5500-4900$ & 280 & 12 & 4.3 & $\begin{array}{l}\text { Bickle et al., } \\
\text { (2013b) }\end{array}$ \\
\hline Germany & MES & $5500-4000$ & 2324 & 200 & 8.6 & $\begin{array}{c}\text { Nicklisch et al., } \\
\text { (2016) }\end{array}$ \\
\hline Germany & MES & $5500-4700$ & 1898 & 161 & 8.5 & $\begin{array}{c}\text { Bock \& } \\
\text { Bruchhaus, } \\
(2003)\end{array}$ \\
\hline Switzerland & Niederried* & $4500-4300$ & 15 & 2 & 13.3 & this study \\
\hline Germany & MES & $4000-3000$ & 490 & 24 & 4.9 & $\begin{array}{l}\text { Nicklisch et al., } \\
\text { (2016) }\end{array}$ \\
\hline Switzerland & Burgäschisee & $3900-3700$ & 8 & 1 & 12.5 & this study \\
\hline Switzerland & Oberbipp & $3350-2650$ & 618 & 49 & 7.9 & this study \\
\hline Switzerland & Aesch & $3100-2500$ & 622 & 24 & 3.9 & $\begin{array}{l}\text { Bay, (1936), this } \\
\text { study }\end{array}$ \\
\hline Germany & MES & $3100-2800$ & 923 & 58 & 6.3 & $\begin{array}{c}\text { Bock and } \\
\text { Bruchhaus, } 2003\end{array}$ \\
\hline Germany & MES & $2800-2000$ & 1609 & 88 & 5.5 & $\begin{array}{c}\text { Nicklisch et al., } \\
2016\end{array}$ \\
\hline Germany & MES & $2500-2000$ & 3347 & 234 & 7.0 & $\begin{array}{c}\text { Bock \& } \\
\text { Bruchhaus, } \\
(2003)\end{array}$ \\
\hline Switzerland & Spreitenbach & $\sim 2500$ & 217 & 15 & 6.9 & $\begin{array}{l}\text { Meyer \& Alt, } \\
\text { (2012) }\end{array}$ \\
\hline Switzerland & Bad Zurzach & $2300-1900$ & 48 & 3 & 6.3 & this study \\
\hline
\end{tabular}

How to cite this article: Siebke I, Steuri N, Furtwängler A, et al. Who lived on the Swiss Plateau around 3300 BCE? Anal- yses of commingled human skeletal remains from the dolmen of Oberbipp. Int J Osteoarchaeol. 2019;1-11. https://doi.org/ 10.1002/oa.2791 


\section{Supplement material figure and table}

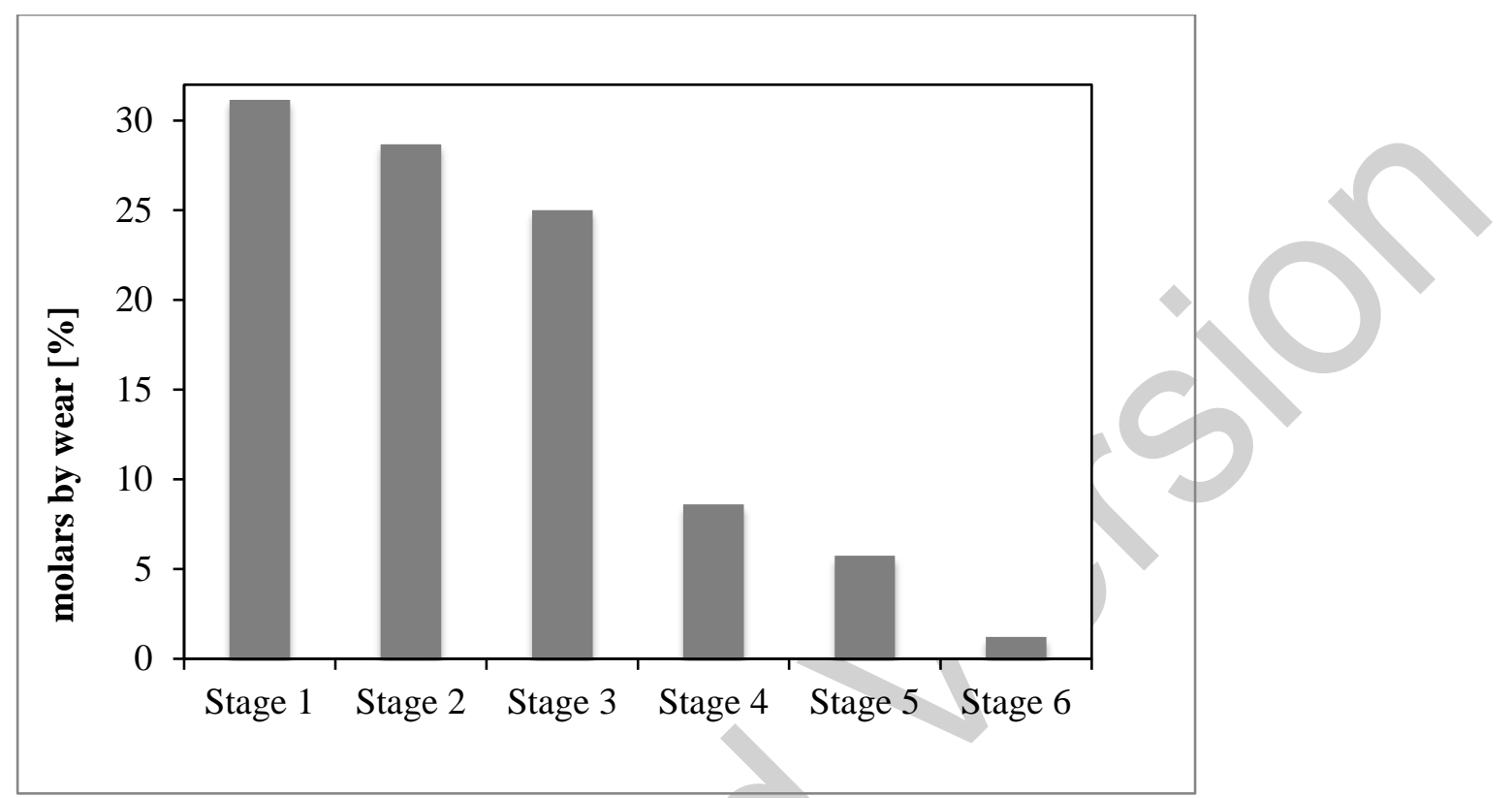

Figure S1: Distribution of molar wear by defined stages. A general decline from stage 1 to 6 is observable ( $N=245$ teeth; stage 1: $n=76$; stage 2: $n=70$ stage 3: $n=61$; stage 4: $n=21$; stage 5: $n=14$; stage 6: $n=3)$. 
Table S1: Average stature estimation from Neolithic sites of Europe. Stature in cm, rounded to one decimal place; ${ }^{*}=$ raw measurement taken from publication, stature calculated using Pearson (1899); "= based on supplement material of the publication; $m=$ male; $f=$ female; id= indeterminate

\begin{tabular}{|c|c|c|c|c|c|c|c|c|c|c|c|c|}
\hline Country & Site & $\begin{array}{l}\text { Date } \\
\text { [BCE] }\end{array}$ & $\mathbf{n}[\mathrm{m}]$ & $\begin{array}{l}\text { Stature } \\
\text { [m] }\end{array}$ & SD & n [f] & $\begin{array}{l}\text { Stature } \\
\text { [f] }\end{array}$ & SD & $\begin{array}{l}\mathbf{n} \\
\text { [id] }\end{array}$ & $\begin{array}{l}\text { Stature } \\
\text { [id] }\end{array}$ & SD & Literature \\
\hline Switzerland & Barmaz I & $\begin{array}{l}4800- \\
3200\end{array}$ & 3 & 156.6 & 1.1 & 3 & 147.7 & 4.9 & - & - & - & $\begin{array}{l}\text { Wyss, } \\
\text { (1998)* }\end{array}$ \\
\hline Switzerland & Barmaz II & $\begin{array}{l}4800- \\
3200\end{array}$ & 5 & 159.6 & 2.2 & 5 & 148.7 & 2.6 & - & - & - & $\begin{array}{l}\text { Wyss, } \\
\text { (1998)* }\end{array}$ \\
\hline Switzerland & Lenzburg & $\begin{array}{l}4400- \\
3200\end{array}$ & 3 & 161.7 & 2.0 & 3 & 146.6 & 0.6 & - & - & - & $\begin{array}{l}\text { Wyss, } \\
\text { (1998)* }\end{array}$ \\
\hline Switzerland & $\begin{array}{l}\text { Pully- } \\
\text { Chamblandes }\end{array}$ & $\begin{array}{l}4100- \\
3700\end{array}$ & 4 & 162.6 & 3.8 & 4 & 152.7 & 3.6 & - & - & - & $\begin{array}{l}\text { Stöckli et } \\
\text { al., (1995); } \\
\text { Wyss, } \\
(1998)^{*}\end{array}$ \\
\hline Switzerland & Schweizersbild & $\begin{array}{l}4000- \\
3500\end{array}$ & 3 & 157.5 & 8.1 & 1 & 142.1 & 3.3 & - & - & - & $\begin{array}{l}\text { Wyss, } \\
(1998)^{*}\end{array}$ \\
\hline Switzerland & Oberbipp & $\begin{array}{l}3350- \\
2650\end{array}$ & - & - & - & - & - & - & 3 & 155.1 & 1.8 & this study \\
\hline Germany & Benzingerode & $\begin{array}{l}3300- \\
2900\end{array}$ & 5 & 162.0 & 6.5 & 4 & 150.3 & 2.9 & 2 & 155.7 & 4.9 & $\begin{array}{l}\text { Meyer et } \\
\text { al., } \\
(2008)^{*}\end{array}$ \\
\hline Italy & Tyrolean Alps & $\sim 3200$ & 1 & 158.6 & 3.3 & - & - & - & - & - & - & $\begin{array}{l}\text { Ruff et al., } \\
(2006)^{*}\end{array}$ \\
\hline Switzerland & Rapperswil & $\begin{array}{l}2900- \\
2500\end{array}$ & - & - & - & 1 & 155.5 & 3.3 & - & - & - & this study \\
\hline Switzerland & Spreitenbach & $\begin{array}{l}2500 \\
\sim\end{array}$ & 3 & 163.6 & 2.9 & 1 & 155.3 & 3.3 & - & - & - & $\begin{array}{l}\text { Meyer \& } \\
\text { Alt, } \\
(2012)^{*}\end{array}$ \\
\hline Europe & Male Average & $\begin{array}{l}5300- \\
2000\end{array}$ & $282 "$ & 163.5 & 1.6 & - & - & - & - & - & - & $\begin{array}{l}\text { Siegmund, } \\
\text { (2010) }\end{array}$ \\
\hline Europe & $\begin{array}{l}\text { Female } \\
\text { Average }\end{array}$ & $\begin{array}{l}5300- \\
2000\end{array}$ & - & - & - & 236" & 151.5 & 2.2 & - & - & - & $\begin{array}{l}\text { Siegmund, } \\
\text { (2010) }\end{array}$ \\
\hline
\end{tabular}

\section{References}

Meyer, C., \& Alt, K. W. (2012). Anthropologische Untersuchung der menschlichen Skelettfunde aus dem endneolithischen Kollektivgrab von Spreitenbach: osteologischer Individualbefund und Populationscharakteristik. In T. Doppler (Ed.), Spreitenbach-Moosweg (Aargau, Schweiz): Ein Kollektivgrab um 2500 v. Chr. (pp. 104-157). Basel: Urs Zuber AG.

Meyer, C., Kranzbühler, J., Drings, S., Bramanti, B., Nehlich, O., Richards, M. P., \& Alt, K. W. (2008). Die menschlichen Skelettfunde aus der neolithischen Totenhütte von Benzingerode. Anthropologische Untersuchungen an den Bestattungen eines Kollektivgrabs der Bernburger Kultur. In H. Meller (Ed.), Die Totenhütte von Benzingerode: Archäologie und Anthropologie (pp. 107-160). Halle: Landesmuseum für Vorgeschichte.

Ruff, C. B., Holt, B. M., Sládek, V., Berner, M., Murphy, W. A., zur Nedden, D., . . Recheis, W. (2006). Body size, body proportions, and mobility in the Tyrolean "Iceman". Journal of Human Evolution, 51(1), 91-101. doi:https://doi.org/10.1016/j.jhevol.2006.02.001

Siegmund, F. (2010). Die Körpergrösse der Menschen in der Ur- und Frühgeschichte Mitteleuropas und ein Vergleich ihrer anthropologischen Schätzmethoden. Norderstedt: Books on Demand $\mathrm{GmbH}$. 
Stöckli, W. E., Niffeler, U., \& Gross-Klee, E. (Eds.). (1995). Neolithikum - Néolithique - Neolitico. SPM II. Basel.

Wyss, R. (1998). Das neolithische Hockergräberfeld von Lenzburg, Kt. Aargau. In S. L. Zürich (Ed.), Archäologische Forschungen. Zürich: Schweizerisches Landesmuseum Zürich. 